\title{
PLEASE COME, SIT, AND SHARE MY VIEW
}

\author{
SEAN BEER \\ Department of Tourism and Hospitality, Faculty of Management, \\ Bournemouth University, Poole, Dorset, UK
}

\begin{abstract}
Communities in general, and rural communities in particular, punctuate their lives with events that bring people together and celebrate aspects of culture. Rural communities in the UK are no exception and there is a heavily populated calendar of rural events, celebrating touchstones such as farming, hunting, and horses. Thus, there are numerous agricultural shows, game fairs, and horse events such as gymkhanas and horse shows. Research with regard to events such as these has been limited. There is a feeling among many people in the rural community that the UK is increasingly dominated by urban, as opposed to rural, concerns and that this cultural influence is changing the nature of many rural events. This article aims to explore and articulate some of these concerns. In order to do this an autoethnographic approach has been adopted as a method, utilizing logocentrism as an ontological lens. I grew up immersed in the culture and traditions of rural UK. I was taken hunting and was attending horse and agricultural shows before I could walk. As a young man I worked on farms and helped organize and run rural events. As such I view(ed) the world from a perspective that reflects my cultural upbringing. I find it difficult living in an urban dominated society where I consider rural events are increasingly urbanized to a point where the life, past and present, of the countryside becomes a sideshow. This commodification of rural life in the UK is something that has local and global relevance, though there are ways that event organizers can address some of these concerns.
\end{abstract}

\section{Key words: Rural; Agriculture; Autoethnography; Logocentrism}

\section{Introduction}

Communities punctuate their lives with events that celebrate aspects of culture and also serve to bring members of those communities together. Rural communities in the UK are no exception to this and their calendar is heavily populated with events that celebrate specific rural touchstones such as farming, hunting, and horses. This is a rich area of cultural experience. For example, in the UK approximately 6 million people per year attend agricultural shows (https://www.asao.co. $\underline{\mathrm{uk} / \text { ) }}$ and many more worldwide. However, coverage in the academic literature appears to be limited (see K. Anderson, 2003; Gray, 2010; Henryks, Ecker, Turner, Denness, \& Zobel-Zurbrzycka, 2016; Holloway, 2004; Joudrey, 2016; Oladele, 2010; Turner, Henryks, Main, \& Wehner, 2017). 
A similar situation seems to exist for equestrian events (see Daniels \& Norman, 2005; Goodrum \& Hunt, 2011; Le Clinche, Martinent, \& Chanavat, 2017; Lee, 2017; Shipway \& Hallmann, 2012) though veterinary and sports science perspectives are better served. This article focuses on rural events such as agricultural shows, game fairs, and horse events such as gymkhanas and horse shows.

Many rural people consider that the UK is increasingly dominated by urban concerns and that this cultural influence is changing the nature of many rural events. Concerns such as these are articulated on a weekly/monthly basis in publications like Country Life, The Field, Shooting Times, Countryman's Weekly, and Horse and Hound. It is also the focus of many organizations such as The Countryside Alliance, The British Association for Shooting and Conservation, and The Campaign to Protect Rural England and gave rise to a protest movement based on a series of marches in London (BBC, 2018; McFarlane, 1998; Woods, 1998, 2003, 2004). This article aims to explore and articulate some of these concerns within the context of rural events using autoethnography as a method and logocentrism as an ontological lens. In the next section I will briefly outline the nature of the events that I am reflecting on before explaining the methodology that underpins the article. Following this I will explore the changing nature of events and rural reality over the last 50 years from a personal perspective, before drawing together some final conclusions and reflections.

\section{The Nature of Rural Events}

Rural events are extremely diverse. To try and develop a comprehensive typology would be to attempt to document the life experience of rural communities. To provide an idea of the breadth of rural events I have developed an outline typology of rural events focusing on three rural touchstones: farming, hunting, and horses. This typology is illustrated in Table 1.

\section{Methodology}

In order to explore the changing nature of these rural events I will use autoethnography as my research method. O’Byrne (2007) considered that autoethnography rests within the ideas of critical theory and postmodernism; hence, it is an appropriate approach to use in the context of this special edition focusing on the use of critical theory. I will draw on my own experiences to, as Jones, Adams, and Ellis (2016) put it, "examine and critique cultural experience” (p. 22). I will do this through the lens of logocentrism, a viewpoint developed by Jacques Derrida (Derrida, 1973, 1978, 1997). Autoethnography is considered an approach that has helped to facilitate much critical theory, particularly as an agent in disrupting the norms of research practice and representation (Jones et al., 2016). I will now explain a little more about the autoethnographic approach and then go on to look at logocentrism as a lens, before reflecting on my experiences of rural events over the past 50 years.

\section{The Approach: Autoethnography}

Ellis and Bochner (2000) consider autoethnography to be: "an autobiographical genre of writing research that displays multiple layers of consciousness, connecting the personal to the cultural" (p. 739).

Jones et al. (2016) maintained that autoethnographic work has four key characteristics:

1. The writer purposefully commentates on/critiques culture and cultural practices.

2. The writer makes contributions to existing research.

3. The writer embraces vulnerability with purpose.

4. The writer creates a reciprocal relationship with audiences in order to compel a response. (p. 22)

Jones et al. (2016) considered that the approach has gained recognition as a result of the challenges to the ways in which scientific knowledge is produced and the growth in qualitative research, and in particular greater appreciation of the body and emotions, as well as narratives and aesthetics. It is also fueled by a greater interest in the ethics of research and particularly concerns with regard to the way that research is "done on/to" participants. Autoethnography has a particular resonance with research that explores social identity and identity politics (Adams, Holman, Jones, \& Ellis, 2014; Denzin, 2013). 
Table 1

A Typology of Rural Events, Focusing on Farming, Hunting, and Equestrianism

General/Type of Event Examples

\section{Farming events}

Events celebrating the changing seasons

Events celebrating rural skills

Events focusing on particular rural groups such as farm discussion groups, Young Farmers Groups, and animal breed societies

Agricultural and horticultural shows
- Harvest festivals; generally religious festivals celebrating the harvest.

- Rogation Sunday; religious festivals blessing the cultivation of the land.

- Wassailing of apple trees; events with a pagan origin blessing apple trees.

- Ploughing competitions.

- Hedge laying competitions (hedge laying is a skill relating to maintaining field boundaries.

- A multitude of events including farm visits, competitions, and social events.

- These are specific events that serve four primary purposes: social gathering, competition, business promotion and agricultural extension. Up to $10 \%$ of the UK population attend these events in any given year (ASAO, 2017). In effect these shows are festivals of the countryside. Some may be small with a few hundred visitors on a single day, some are large with 150,000 visitors over a number of days.

\section{Hunting events (hunting, shooting, and fishing)} Practical hunting events

Social events based on individual hunts, shoots or fishing groups

Social events involving the broader hunting community

\section{Equine events \\ Sporting events and competitions}

Social events
- Meets of hunters on horseback or foot to engage in hunting pest animals with hounds (dogs). In the UK, with some exemptions, the hunting of animals with dogs was banned in 2004 by the Hunting Act (UK Gov, 2004). Most hunts converted to trail hunting, where the hounds follow an artificial scent. Shooting mainly refers to the shooting of birds and deer. Bird shooting is often done within a social setting; fishing tends to be a more individual occupation.

- Puppy Shows; where the quality of the new hounds are judged.

- Field Trials; where dogs used to retrieve shot game are tested.

- Clay Pigeon Shoots; shooting artificial bird targets.

- Fishing Matches, competitive fishing events.

- Other social events, games evenings, barbecues, balls.

- Hound shows; regional competitions for hounds often taking place in an agricultural show such as Honiton (http://www.honitonshow.co.uk/).

- Hunting festivals; national gatherings such as Peterborough (https://festival ofhunting.com/).

- Game Fairs; such as Lowther (http://www.lowthershow.co.uk/) or The Game Fair (https://www.thegamefair.org/).

- Horse trials; cross-country events for amateur and professional riders. Steeplechasing.

- Horse racing, including Point to Pointing as indicated above.

- Various competitions relating to the different equine disciplines such as Dressage, Show Jumping, Three-Day Eventing, and Gymkhana. Also, clinics and demonstrations.

- Horse shows; where horses are judged on their appearance and confirmation.

- Again, a wide range of social events including fundraising evenings, lectures, dinners, and social riding events.
- Point-to-point racing; a form of artificial cross-country horse racing or
L. Anderson and Glass-Coffin (2016) indicated that there are a number of different elements that may combine into a method. These include the use of field notes, personal documents and artifacts, and interviews. In writing this article I am reflecting back over a period of 50 years. I do not have field notes as such, though I have written quite widely on rural issues in a range of publications (see for example, S. C. Beer, 1994; 2015; A. E. Beer \& Beer, 1998, 1999, 2000) and some of these have provided evidence upon which to reflect. I have also amassed a collection of books on multiple aspects of the countryside, a collection of photographs, and a collection of catalogues to 
events such as agricultural shows, livestock auctions, and livestock Breed Society events as well as associated herd and flock books (breed society records of members and livestock). However, the main focus of the method that I have employed is the autoethnographic interview, a process that gives rise to reflections on what Crawley and Husakouskya (2016) called, “scenes from one's reflected life experiences” (p. 336). These interviews have taken place over an extended period of time. Initially they were informal periods of thought and reflection, often initiated by a specific event such as a visit to an agricultural show. They became more structured for the purpose of producing this article. As such they reflect the "rigorous, nuanced, and legitimate research practice" described by Holman Jones, Adams, and Ellis (2016, p. 31), and further elaborated upon by L. Anderson and Glass-Coffin (2016), Chang (2016), and Denzin (2016). In all this I have endeavored to be strongly visible, reflexive, engaging. and also, I have let myself be potentially vulnerable (L. Anderson \& Glass-Coffin, 2013). The accounts presented here are not meant to be closed in terms of providing a final statement, but reflective of a life lived on the borders of urban and rural cultures. As such, I believe that this approach does fulfil the purposes of autoethnography; it does disrupt the norms of research practice, works with insider knowledge, maneuvers through anxiety, and speaks for a silent constituency. In all I hope that the work is accessible (Bolen, 2012; Jones et al., 2016). I would now like to focus on my use of logocentrism.

\section{The Lens: Logocentrism}

Although the ideas of binary opposition and logocentrism are explored in a number of areas of poststructuralist/postmodernist thought (Belsey, 2002; Connor, 1997; Sim, 1998), I came to these ideas through reading texts by Derrida (1973, 1978, 1997). In essence, Western thought is based on a center; that is, a principle idea that is privileged above others and gives rise to all meaning. The central idea marginalizes and oppresses others. Thus, in paternalistic societies that are male dominated, man is central, and woman is marginalized. The two are in a state of binary opposition. At the center of this way of seeing the world is the idea of logos.
Logos is a Greek term that means truth, reason, or, after Heraclitus, a principle of order and knowledge (Audi, 1999). Derrida employed an approach to his examination of knowledge that involved trying to deconstruct these binary oppositions. He maintained that there were no fundamental truths, origins, or causes that underpinned knowledge. In particular, there was no transcendental signified that guarantees meaning and was critical of the logocentric discourses that seem to dominate Western lives, be they male as opposed to the female, white as opposed to black, or straight as opposed to gay, for example. He talked about a metaphysics of presence, that "all the names related to fundamentals, to principles, or to the centre have always designated an invariable presence" (Derrida, 1978, p. 353).

If there can be a metaphysics of presence, should there not also be a metaphysics of absence? Therefore-in taking this perspective-if we look at our lives and the lives of others and we see patriarchy, we ask, where is the female voice? If we look at a white society, where is the black voice? If we look at the world and see the urban, where is reality? This approach has allowed me to open up the world. It has caused me to consciously look for the suppressed voices and to investigate the qualities of absence. Often it is not that these voices are silenced, but that they are repressed, ignored, pushed to the margins, gradually eroded to a point where they may disappear. Over the past 30 years, there has been extensive discussion of this in books and the more popular countryside literature previously alluded to. It is this lens of analysis that has allowed me to give structure to my experiences of the marginalization of many rural voices in our increasingly urban dominated culture. In the following reflections, I explore this tension between urban and rural in the context of rural events. Initially, I would like to describe two very important and characteristic experiences.

\section{The Overview}

It is the late 1980s and I have parked my car and am walking up across a field in North Devon. I have to walk up a slope before I reach the pens made out of galvanized hurdles that contain two or maybe three sheep per pen. There will be several hundred sheep in total. People are milling round, trimming 
the wool and grooming the sheep in preparation for the various classes, because this is a sheep show. The sheep will have done this for generations. For the most part, the exhibitor's families will also have done this for generations. The two principal breeds of the area, Devon Closewool and the Exmoor Horn, are in the majority. There are very few trade stands, possibly one selling animal feed and another selling drenches (oral medicines) against worms and other parasites. There is the Secretary's tent and also a tent where you can buy cakes, sandwiches, pasties (meat and vegetables in a pastry case traditional to the south-west of the UK), and a cup of tea or coffee. I feel a strong sense of belonging.

It is now 2017 and I am walking round a large agricultural show in the south-west of the UK. We have come on the first day, which is traditionally the day when most of the farming community come to the show, and I go down to watch the sheep judging. I search in vain to find the classes for the Devon Closewools. They are not being judged today, as they always have been before, but tomorrow. It is the same with the sheep shearing (there are classes for competitive sheep shearing-cutting the wool fleece from a sheep-based on speed and accuracy). The change seems to have been put in place in order to provide more entertainment over the other days of the show. As I move away from the area where the cattle, pigs, and sheep are housed, I move off into a world dominated by trade stands selling sunglasses, patio heaters, raincoats, and garden furniture. There seems to be very little of farming and the countryside. I feel as if I am in an alien world and almost a curiosity, as the people around me seemed to be from a different urban cultural background. They have no real interest in sheep. I feel claustrophobic.

These two reflections represent contrasting experiences that exemplify how the nature of rural events is changing over time. I would now like to reflect on some of my life experiences to provide context to this.

\section{The Story}

\section{Childhood (1960s-1970s): My Initial Memories}

As a child, I was brought up in the traditions of the countryside. My father was an agricultural adviser. When he left school, he had been a farm worker, as had previous generations of his family. My mother came from a more urban background; however, I was drawn to the countryside. I can see myself at the age of about 2, wearing a blue rain suit with a white collar, at a meet of foxhounds. I can actually see myself, because I am looking at a photograph that my father would have taken. In the background sits the Huntsman on a horse talking to a man in a raincoat. The hounds stand and sit, looking expectantly at the Huntsman. These are ordinary people. This is ordinary life. I can now see myself, probably 12 months later this time, wearing a white coat and red wellingtons (waterproof boots) walking among the hounds, and posing for a photograph with the Huntsman on his horse. I am, again, looking at photographs, but I can remember that coat, those wellingtons, and sitting on that horse. I can remember many occasions such as this. I can also remember being taken to agricultural shows. Looking at animals; getting fairly close to the sheep, but more distant from the cattle and horses. Flower shows were also important. My father and grandfather were great growers and exhibitors of fruit, vegetables, and flowers. I can remember traveling down to Devon, entering the marquee, smelling the crushed grass and the damp canvas of the tentage; a smell that still arouses memories like Proust's madeleines reminded him of his mother (Proust, 1927). It was always exciting, because my grandfather would have entered me for a competition, such as a collection of wildflowers. Many people might be critical of these experiences. Taking a child to a meet of the foxhounds, an exhibition of animals exploited for pleasure or destined for the abattoir, picking wildflowers. However, this was, and in many ways still is, simply part of country life. At that age, I did not even know it was country life, it was simply life.

\section{Youth (1970s-1980s): A Strengthening of the Rural Bond}

At the age of 16 , we moved to a small farm in North Devon. North Devon is a fabulously rural area of the south-west of the UK. When I got the opportunity, I worked on the farm. At school, I was drawn to work by poets such as RS Thomas and Ted Hughes. Thomas spoke of a deep understanding of 
the reality of rural life and rural people through poems such as Iago Prytherch, Peasant Greeting, and A Peasant,

Iago Prytherch his name, though, be it allowed, Just an ordinary man of the bad Welsh hills, Who pens a few sheep in a gap of cloud.

Docking mangels, chipping the green skin From the yellow bones with half-witted grin. Thomas (1996, p. 3)

Hughes had a fundamental insight into the beauty and brutality of nature. In poems such as View of a Pig, An Otter, Thrushes, and Pike he made a connection that I think many country people understood, but many urban people lose in a flood of anthropomorphism,

Pike, three inches long, perfect

Pike in all parts, green tigering the gold.

Killers from the egg: the malevolent aged grin.

They dance on the surface among the flies.

Hughes (1982, p. 52)

It was also at this time that I first experienced the work of James Ravilious (Beacham \& Ravilious, 2008; Ravilious, 1995), a photographer based in North Devon, whose work is now stored at the Beaford Archive (Beaford, 2017). Ravilious produced beautifully evocative unairbrushed photographs of the people and landscapes of North Devon. There was no sanitization, documented by Hughes when he said,

Buried in their deep valleys, in undateable cobwalled farms hidden not only from the rest of England but even from each other, connected by the inexplicable, Devonshire, high-banked deepcut lanes that are more like a defence-maze of boroughs, these old Devonians lived in a time of their own. It was not uncommon to hear visitors say: 'Everything here's in another century!' But what they really meant, may be, was that all past centuries were still very present here, wide-open, unchanged, unexorcized, and potent enough to overwhelm any stray infiltrations of modernity. The farmers lived lightly in the day and the year, but heavily in that long backward perspective of their ancient landscape and their homes. The breed was so distinct, so individualized and all of a piece, they seem to me almost a separate race. (Hughes, 2012, p. 1203)

The other literary keynote was Henry Williamson. Famous for his book Tarka the Otter (Williamson,
1927), which told of the birth, life, and death of an otter in the land of the two rivers (North Devon), I was more interested in his books about village life in North Devon between the first and second world wars; for example, The Village Book (Williamson, 1933) and Tales of the Devon Village (Williamson, 1944). These books were in turn funny and tragic, but told of an intimate relationship between life, land, and landscape.

The family business gradually expanded to include running two livestock breed societies, one for cattle and one for sheep, and also to running events; initially a country fair and later a 1-day agricultural show with 20,000 visitors. There was an underlying philosophy to these events, which my father sometimes spoke about, though mostly it was just considered a priori, this is just what we did. The events were designed to celebrate the countryside, farming, local food, and drink. For example, we introduced one of the first local food halls at an agricultural show. Sometimes, these celebrations could be humorous. One year we held the World Hogs Pudding Championship, the Hogs Pudding being the local white sausage of the region. The name Hogs Pudding seems to make people laugh, as does the interest in a local sausage. In all this, there was a desire to engage and nurture community and to give people a good day out. It seemed that this was the major focus of the various rural events that I attended; community, ruralness and "a backward (as well as forward) perspective” (Hughes, 2012, p. 1203). At these events there would be parades of foxhounds, but there were no demonstrations; people knew that others objected to foxhunting, but views were respected on both sides. There was a great interest in seeing the livestock, even though everybody knew the ultimately these animals would enter the food chain in one way or another. There was a respect for local traditions and crafts, accents, and songs, but things had started to change.

\section{Adulthood (1980s-2000s)}

In many ways, this period of time has seen vast change in general in a country like the UK, and in particular in its rural areas. I think that increasingly the UK has become dominated by urban perspectives that have led to significant changes in rural culture and events. 
It is about 2000, and I am at a large agricultural show in the south of the UK. I have really been looking forward to the visit. The show was established a long time ago and I am hoping to be immersed in the rural community and culture of an area with which I am not familiar. I am shocked and disappointed; the show appears as a cross between a shopping mall and a car boot sale. I hunt for the livestock and eventually find them hidden away in a corner. The show is very well-off in financial terms, there are many people here from a large local conurbation and that is from where the show gets its income, but I feel that they have changed the nature of the event to suit their urban customers. The agricultural and the rural bits seem to take the form of cameo appearances. The rural community appear as actors in some sort of theme park. It is really unsettling, and I will not come again.

I consider that this process of change in the culture of rural events has three main foci. The first is the decline in the agricultural element of many county/agricultural shows and other rural events. It is not only the size, but the quality of the agricultural element. One large event that I went to last year had, in effect, a farm livestock section that was little more than a petting zoo. A second focus is the ubiquitous rise of shopping trade stands and the decline in country trade stands. Thus, we have the endless malls of local country crafts fresh from far away across the sea and generic food halls selling repackaged, industrially produced food, maintaining that it was produced in a kitchen or down on the farm. The third focus is the almost apologetic way that agricultural shows have displays related to field sports. At one time, these displays were simply part and parcel of events, but increasingly they have become something that needs to be apologized for, to be explained, as the audience seems to become increasingly disconnected. For me, this represents the growing strength of the urban locus. Many people have talked about the effect of incomers from the towns on the countryside or the gentrification of rural Britain (Newby, 1985), and I will discuss this later; however, gentrification is probably not the right word. Just as the current process of gentrification of our urban areas (Gravari-Barbas \& Guinand, 2017) is probably more postmodernification then rural gentrification has probably been more about urbanification. As one Exmoor Hill farmer said of a neighbor who had trimmed the verge either side of the gateway going up to his house, "so now we have been urbanized.”

\section{Middle Age (2000s to the Present Day)}

From my current position, I can say that the process of the urbanization of rural events has continued, as has my unease. It is quite possible that this represents the broader changes in British culture where the urban locus has gradually marginalized the rural, leading to erosion of rural culture, society, economy, and environment. There are many touchstones with regard to this broader process. I would like to briefly look at two; attitudes to farming and to hunting. During and following the Second World War, British agriculture was geared up to supply food as efficiently as possible to the largely urban population (Body, 1982). This pressure continued when the UK entered the European Union. Indeed, promoting technical progress in terms of agricultural production forms the first subsection of Title II, article 39 of the Treaty of Rome (EEC, 1957). At the same time, often rightly, considerable concern has been and is expressed at the way in which food is produced and the effect of this production on the environment and those that consume the food (Blythman, 1996; Carson, 1962). However, in many ways as I have said before (S. C. Beer, 2017a, 2017b) this criticism by the general public is misplaced, as they ultimately control policy through the ballot box and also control the market, in terms of the food that they decide to purchase, and thus the systems of production that are used to produce food and the environment that results.

Aspects of rural culture have also been increasingly criticized, such as hunting with hounds. Hunting with hounds in the UK was banned in 2004 (HMG, 2004). Between 2005 and the October 2017, there have been 35 completed cases under the Hunting Act involving hunts registered with the Council of Hunting Associations. Fifteen of those cases were proven and led to 27 convictions. There are over 300 registered hunts in the UK and Wales. Together, they have carried out over 150,000 days hunting since the Act came into force on February 18, 2005 (Countryside Alliance personal communication, 2017). This would seem to indicate that hunts are hunting largely within the law. Recently 
a group of activists sought to ban legal hunting on land owned by the National Trust, a British conservation charity, the activists cited an International Fund for Animal Welfare (IFAW, 2015) report on hunting that seem to indicate that "a genuine trail hunting event, rather than a fake one (presumably referring to illegal hunting) only took place in $0.04 \%$ of cases" (National Trust, 2017, p. 8). If this is the case why aren't there more successful prosecutions? Why is there this continuing animosity? This tension overspills at rural events. For example, this summer the Asby de la Zouch Agricultural Society faced increasing pressure from antihunting groups to ban local hunts from appearing at the show; the show went on with their parade of hounds ("Hound Parade Continues," 2017). The ethics of hunting and animal rights has been discussed by many different commentators (DeGrazia, 2002; Page, 2000; Scruton, 1998; Singer, 2015). I agree that there are aspects of hunting that may be considered cruel; however, there is a gross hypocrisy here when we look at other aspects of nature and life; for example, how our food is produced, and the suffering that is incurred in its production. Chickens for human consumption are raised in sheds, often of 30,000 birds. The animals grow to maturity in 5 or 6 weeks (Soffe, 2003; Wright Ltd, 2018). They then enter an industrial transport, slaughter, and processing system (Bell \& Weaver, 2012). There are serious concerns with regard to the welfare of these animals in this supply chain, yet chicken is one of the most widely consumed meats in the UK, with its population consuming 2.2 million chickens per day (Bekhechi, 2016). What about the suffering of the chickens? But this lack of feeling is not surprising. I recently attended a conference session that was focused on animals in tourism. There was much discussion about the suffering of animals in zoos and sled dogs, but very little interest when I tried to raise the idea that, in terms of animal suffering, the food that the tourists consumed was of far greater concern. Such Benthamite ideas of multiples of suffering could not compete with the face of a fluffy husky dog or a monkey. Also, what about the fish? The fish that we eat is caught in nets and suffocated. Why is hunting such a target and these other activities are not in the same way? Ultimately, we all draw lines in the sand at arbitrary points and to maintain that human beings are economic rationalists (as proposed by economists) is not supported by human behavior. I think that both these factors, criticisms of farming and criticisms of hunting, represent a lack of understanding of the broader context of our lives that results in the marginalization of rurality.

This does not mean that there are not also tensions within the rural locus. Historically, there have been great differences in wealth, social status, land, and home ownership. My father's family were farmworkers. My grandfather was always a farm worker, my father was a farm worker when he left school, as was I. I benefit from the fact that that an academic scholarship meant that my father went to a good school and then to a university. I live very close to the village of Tolpuddle in Dorset, the home of the Tolpuddle Martyrs, the oppression of whom led to the formation of the first trades union. But in all this, there was/is still a feeling of community; even if there was injustice, there was belonging. In a broader sense feelings of community appear to be increasingly dying out, being replaced by an individualistic attitude to life. This is fueled by ideas of consumerism, where people consider that they are first and foremost a consumer of things — with rights, but no responsibilities. The countryside is something to be consumed, not to belong to, and anything apart from that isolated act of consumption is irrelevant; in effect, the countryside is a commodity.

Yet many of the rural events that continue to be successful tap into ideas of community. However, it is interesting to see how some of these ideas of community break down. I am a member of an agricultural society. This membership entitles me to attend the society's show without paying the gate fee. In years when there is bad weather it may be that the show is cancelled, in which case I remain a member of the society/show, but there will be no show to attend. It is interesting to see the number of individuals who, when the show is cancelled because of wet weather, seek to get a refund of their membership. They do not seem to understand that it is a shared experience, where the risks and benefits are shared by a community. It is possible that some of this lack of community is regional. In many parts of the far south-west of the UK, Wales, the north of the UK, and in the Scottish Borders, 
I have experienced greater feelings of community, and what I consider to be more community-based rural events. For example, during the summer in the border areas of Scotland and the north of the UK there are multiple agricultural shows (Gray, 2010). In the Lake District, in the north-west of the $\mathrm{UK}$, it is possible, during the summer months, to go to a different agricultural show every weekend to see local livestock, local customs and crafts, and to hear local accents, and, even if an outsider, to feel at home. I remember as a young man traveling in Yorkshire, driving along a road in the country and seeing a gate hanging off its hinges. Propped up against the gate was a little sign saying "show." I went in by chance and ended up at very local agricultural show with traditional attractions such as hound trailing (where hounds race each other following a prelaid scent trail) and where the local women (and it was the women) took great pride in providing afternoon tea using the bone china from their homes.

I think that many rural events have responded to commercial individualism, with potentially unforeseen results. Increasingly, because of urban migration many of those running events come from an urban background and have urban values. Those that run events also wish to grow the events. Partly, this is a result of the professionalization of event management; more money is needed to pay the professional event manager. Originally many events were run by amateurs, sometimes in parallel to their job (for example, many agricultural shows were run out of the offices of rural surveyors) or as a hobby. This meant that overheads were low. Now the events need to attract visitors and grow to maintain what they have become. The easiest way to do this is to commercialize the event; to draw in large numbers of visitors from large urban conurbations; to commoditize the experience and it is easy to fill an event with trade stands. These visitors want different things. At the same time there might be an underlying feeling that it is necessary to stage the event, so that people with little knowledge will be better able to understand what they are seeing (Holloway, 2004). Unfortunately, if not done well, this can dumb down the whole event and can also appear to be very patronizing. However, I think that there is hope.
This summer, I have been to many rural events and shows. I have become increasingly selective. I can no longer be bothered to travel to an event that will be a disappointment, but there are still some gems. Exford Show takes place on the top of Exmoor (south-west UK). When you arrive, a human being, who will talk to you, directs you to the parking. I like to park next to the main ring. The event includes the annual show of the Exmoor Pony Society. There is a sheep show featuring Exmoor Horn and Devon Closewool sheep; in some years, they have had classes for any other breed, which makes me laugh, as in most shows these local breeds would be in the minority, but here they reign supreme. There will be a range of classes judging Hunters. Some of these will be Ridden Hunter classes where the judge actually rides the horse. The riders are kitted out in Ratcatcher dress, which is a tweed jacket, tie, and, traditionally, fawn breaches, brown boots, and a hunting bowler hat, though black boots and riding safety hats are now commonly worn. Nobody thinks that this is strange, nor do they take a second glance if someone is walking round in a tweed jacket carrying a shepherd's crook. There are also classes for ponies and show jumping. There is a specific competition for stags' horns and a dog show. The trade stands are limited and reflect local businesses. There is a craft tent and another tent selling local produce. You can have a cup of coffee or a beer and a pasty or fish and chips. All in all, it is something that is perfectly set in its time and place. I feel connected, at home. The parade of staghounds is met with cheers. The view across the Moors is breathtaking.

I am now up in the Lake District in the north of the UK. As I said, possibly there is a regional effect to this urbanization of rural events, because in the Lake District and the Borders you can go to an agricultural show every weekend in the summer. I am at Dalston Show. It is brilliant. There are livestock classes, vintage machinery, and a fantastic horticulture and home craft tent. One thing that I have always wanted to see is Cumberland and Westmorland wrestling. This used to be the domain of men wearing elaborately embroidered long underwear, but now males and females compete (and in the junior classes they compete together), and they wrestle in shorts and T-shirts. There is a great spirit, 
as some of the weight classes are quite broad with small wrestlers taking on big wrestlers, but it is great to see the camaraderie and the mutual respect.

A few days later I am at Lowther Show. I had not been for many years, but to be quite honest, it was better than I remembered. The first section I visited was dedicated to crafts, in particular, stick dressing (the making of different types of walking stick including shepherds' crooks). There was then an area that focused on testing gundogs (dogs used to flush and retrieve shot game) including retrieving across, in, and alongside a river. Next to this was an area dedicated to fishing, with an emphasis on fly fishing, which sat alongside an arena demonstrating aspects of carriage driving that included competitors taking part in the crosscountry section of the various carriage driving competitions. Up from that was food and retail, but stands that seemed far more appropriate to the rural setting. Finally, at the top of the showground was a whole area devoted to hunting. Although there were things that I saw that, as I have already indicated, I would question, I felt at home.

\section{Conclusions and Reflections}

In this article my aim was to explore and articulate concerns that the UK is increasingly dominated by urban, as opposed to rural, concerns and that this cultural influence is changing the nature of many rural events. In order to do this, an autoethnographic approach was adopted as a method, utilizing logocentrism as an ontological lens. Over the past 30 years the nature of many rural events has changed, I believe, primarily because of the growth and power of the urban locus that increasingly dominates the UK from its powerbase in the cities and towns and increasingly in the countryside, as it marginalizes the elements of rural culture. This locus is consumer driven and individualistic, purchasing items and experiences, but with no real connection to the economic, social, and environmental communities that this represents, above and beyond the transaction. This is associated with a tendency to demand immediate gratification and a general lack of understanding about how human beings interact with the environment in the countryside, historically and today. I have a general feeling that this urban locus simply does not care. Possibly it would be better to call this power the urban locust; individualistic, uncaring, focused on instant gratification before moving on. Many rural events have been, and are being, influenced by this because of the increasingly urban backgrounds of the people that are running them, and the way that they pander to the urban population in order to get visitors through the gates and increase visitor spending. This is more and more necessary because of the cost of running events and the perception that it is important to grow. As someone who seeks to engage with the more genuine, authentic, and rich culture of the countryside and its myriad events, this means that I have become far more discerning and consciously seek out events where I will find real gatherings of like-minded souls.

However, if event organizers wish to halt the marginalization of rural culture in their "rural events" then there are three things that they can do. Firstly, they can look back to their terms of reference; the original remit of the societies and associations that put on many of these rural events was based in agriculture and the rural community of which the farms were part. Therefore, secondly, they can hold true to this remit and facilitate a celebration of rural culture. This may well mean subsidizing and looking after those with truly rural trade stands and those who bring livestock and demonstrations of rural culture to shows; but if this is the primary focus of the event, why not? Finally, many event organizers maintain that they need to attract the general public to make sure that shows are viable and also to help educate the public about rural life; however, if increasingly the element of rural life celebrated at shows is minimal, then what is left to celebrate? If this means that shows get smaller then so be it. Surely it is better to have something that is a true celebration of the countryside rather than events that are increasingly of the countryside in name only and more akin to a small ephemeral theme park attached to a shopping mall.

This article is dedicated to all the country people that carry the torch of rural authenticity and for those that have gone on before, in particular, Albert, who fought so hard to maintain the rural traditions and values of countryside events, and Bill, from whose memorial the title for this article is derived. 
References

Adams, T. E., Holman Jones, S., \& Ellis, C. (2014). Autoethnography (understanding qualitative research). Oxford, UK: Oxford University Press.

Anderson, K. (2003). White natures: Sydney's Royal Agricultural show in post-humanist perspective. Transactions of the Institute of British Geographers, 28, 422-441.

Anderson, L., \& Glass-Coffin, B. (2013). I learn by going. Handbook of Autoethnography, 57-83.

Anderson, L., \& Glass-Coffin, B. (2016). I learned by going. Autoethnographic modes of enquiry. In S. H. Jones, T. E. Adams, \& C. Ellis (Eds.), Handbook of autoethnography (pp. 57-83). Oxford, UK: Routledge.

Audi, R. (1999). Cambridge dictionary of philosophy (2nd ed.). Cambridge, UK: Cambridge University Press.

BBC. (2018). Huge turnout for countryside march. Retrieved from http://news.bbc.co.uk/1/hi/uk/2274129.stm

Beacham, P., \& Ravilious, J. (2008). Down the deep lanes. Oxford, UK: The Bardwell Press.

Beaford. (2017). The beaford archive. Retrieved from http:// www.beaford-arts.org.uk/archive/

Bekhechi, M. (2016). Chicken accounts for half the meat eaten in the UK-but here's why it's not as good for you as you might think. Retrieved from http://www.independent. co.uk/voices/chicken-accounts-for-half-the-meat-eatenin-the-uk-but-here-s-why-it-s-not-as-good-for-you-asyou-a6862791.html

Beer, S. C. (1994). Weaknesses to overcome: Breeders will have to overcome a number of weaknesses and threats if Devon Ruby cattle are to increase their sphere of influence in the beef market. Farmers Guardian, November 11,3 .

Beer, A. E., \& Beer, S. C. (1998). Red rubies, jewels in Exmoor's Crown. Exmoor, 4, 16-18.

Beer, A. E., \& Beer, S. C. (1999). From the Porlock to the Exmoor. Albert and Sean Beer discuss the Exmoor Horn, Exmoors native horned sheep. Exmoor, 6, 12-14.

Beer, A. E., \& Beer, S. C. (2000). Closewool country. Albert and Sean Beer discuss an Exmoor breed, the Devon Closewool. Exmoor, 10, 20-22.

Beer, S. C. (2015). Down memory lane. It's show time! In conversation with William and Henry Dart. The Exmoor Magazine, 72, 18-20.

Beer, S. C. (2017a). Letter of the week. Country Life, 56.

Beer, S. C. (2017b). Crying the moor. The Exmoor Review, 59, 22-24

Bell, D. D., \& Weaver, W. D. (2012). Commercial chicken meat and egg production. New York, NY: Springer.

Belsey, C. (2002). A very short introduction to poststructuralism. Oxford, UK: Oxford University Press.

Blythman, J. (1996). The food we eat. London, UK: Michael Joesph.

Body, R. (1982). Agriculture: Triumph and the shame. London, UK: Avebury.

Bolen, D. M. (2012). Toward an applied communication relational inqueery: Autoethnography, co-constructed narrative, and relational futures. Unpublished doctoral dissertation, Wayne State University, Detroit, MI.

Carson, R. (1962). Silent spring. Boston, MA: Houghton Mifflin Harcourt.

Chang, H. (2016). Individual and collaborative Autoethnography as method. A social scientist's perspective. In S. H. Jones, T. E. Adams, \& C. Ellis (Eds.), Handbook of autoethnography (pp. 107-122). Oxford, UK: Routledge.

Connor, S. (1997). Post-modernist culture. An introduction to theories of the contemporary (2nd ed.). Cambridge, UK: Blackwell Publishers Ltd.

Crawley, S. L., \& Husakouskya, N. (2016). A coautoethnography of politics, pedagogy and theory in drag. In S. H. Jones, T. E. Adams, \& C. Ellis. (Eds.), Handbook of autoethnography (pp. 321-338). Oxford, UK: Routledge.

Daniels, M. J., \& Norman, W. C. (2005). Motivations of equestrian tourists: An analysis of the colonial cup races, Journal of Sport \& Tourism, 10(3), 201-210.

DeGrazia, D. (2002). Animal rights: A very short introduction. Oxford, UK: OUP.

Denzin, N. K. (2013). Interpretive autoethnography (qualitative research methods). London, UK: Sage Publications.

Denzin, N. K. (2016). Interpretive autoethnography. In S. H. Jones, T. E. Adams, \& C. Ellis (Eds.), Handbook of autoethnography (pp. 123-142). Oxford, UK: Routledge.

Derrida, J. (1973). "Speech and phenomena" and other essays on Husserl's theory of signs [Translated by D. B. Allison]. Evanston, IL: Northwestern University Press.

Derrida, J. (1978). Writing and difference [Translated by A. Bass]. Chicago, IL: University of Chicago Press.

Derrida, J. (1997). Of grammatology [Translated by G. C. Spivak]. Baltimore, MD: John Hopkins University (Originally published 1967).

Ellis, C., \& Bochner, A. (2000). Autoethnography, personal narrative, reflexivity: Researcher as subject. In N. K. Denzin \& Y. S. Lincoln (Eds.), Handbook of qualitative research (pp. 733-768). Thousand Oaks, CA: Sage Publications.

European Economic Community. (1957). Treaty establishing the European Economic Community. London, UK: HM Stationary Office.

Goodrum, A. L., \& Hunt, K. J. (2011). Framing rural fashion: Observations from Badminton Horse Trials. Visual Communication, 10(3), 287-324.

Gravari-Barbas, M., \& Guinand, S. (2017). Tourism gentrification in contemporary metropolises: International perspectives (Contemporary geographies of leisure, tourism and mobility). London, UK: Routledge.

Gray, J. (2010). Local agricultural shows in the Scottish Borders. Journal of the Royal Anthropological Institute, 16, 347-371.

Henryks, J., Ecker, S., Turner, B., Denness, B., \& ZobelZurbrzycka, H. (2016). Agricultural show awards: A brief exploration of their role marketing food products. Journal of International Food and Agribusiness Marketing, 28(4), 315-329. 
HMG. (2004). Hunting Act 2004. Retrieved from https:// www.legislation.gov.uk/ukpga/2004/37/contents

Holloway, L. (2004). Showing and telling farming: Agricultural shows and re-imaging British agriculture. Journal of Rural Studies, 20, 310-330.

Holman Jones, S. H., Adams, T. E., \& Ellis, C. (2016). Handbook of autoethnography. Oxford, UK: Routledge.

Hound parade continues at Ashby Show. (2017, June 28). Countryman's Weekly, p. 1.

Hughes, T. (1982). Selected poems 1957-1981. London, UK: Faber and Faber.

Hughes, T. (2012). Ted Hughes. Collected poems. London, UK: Faber and Faber.

International Fund for Animal Welfare. (2015). IFAW Uncovering the Trail of Lies Overview Report. Retrieved from http://www.ifaw.org/united-kingdom/resource-centre/ ifaw-uncovering-trail-lies-overview-report

Jones, H. J., Adams, T. E., \& Ellis, C. (2016). Coming to know autoethnography is more the method. In S. H. Jones, T. E. Adams, \& C. Ellis (Eds.), Handbook of autoethnography (pp. 17-48). Abingdon, UK: Routledge.

Joudrey, S. L. (2016). What a man: Portrayals of masculinity and race in Calgary stampede ephemera. Cultural Studies, Critical Methodologies, 16(1), 28-39.

Le Clinche, S., Martinent, G., \& Chanavat, N. (2017). Consumers' attachment in the sporting equestrian context: A cluster analytic approach. Managing Sport \& Leisure, 22(3), 234-254.

Lee, M. A. (2017). Reimagining the races: The case of emerging adults and their composite perspective. Event Management, 21(1), 27-45.

MacFarlane, R. (1998). What-or who-is rural Britain? Town and Country Planning, 67(5), 184-188.

National Trust. (2017). Members' AGM. Swindon, UK: National Trust.

Newby, H. (1985). Green and pleasant land. Hounslow, UK: Hutchinson \& Co.

O'Byrne, P. (2007). The advantages and disadvantages of mixing methods: An analysis of combining traditional and autoethnographic approaches. Qualitative Health Research, 17(10), 1381-1391.

Oladele, I. O. (2010). Student knowledge and attitudes towards agricultural shows and fairs in Botswana. NACTA Journal, December, 45-48.

Page, R. (2000). The hunting gene. Ludlow, UK: Bird's Farm Books.

Proust, M. (1927). Remembrance of things past. Volume 1: Swann's Way: Within a budding grove [Translated by
C. K. Scott Moncrieff and T. Kilmartin]. New York, NY: Vintage.

Ravilious, J. (1995). A corner of England. North Devon landscapes and people. Tiverton, UK: Devon Books.

Scruton, R. (1998). On hunting. London, UK: Yellow Jersey Press.

Shipway, R., \& Hallmann, K. (2012). Determinants of volunteer motivation and their impact on future voluntary engagement: A comparison of volunteer motivation at sport events in equestrian and handball. International Journal of Event and Festival Management, 3(3), 272-291.

Sim, S. (1998). The icon critical dictionary of post modern thought. Cambridge, UK: Icon Books.

Singer, P. (2015). Animal liberation. London, UK: Bodley Head.

Soffe, R. J. (2003). The agricultural notebook. Oxford, UK: Blackwell Publishing Company.

Thomas, R. S. (1996). R. S. Thomas every man's poetry. London, UK: Orion.

Turner, B., Henryks, J., Main, G., \& Wehner, K. (2017). Tinkering at the limits: Agricultural shows, small-scale producers and ecological connections. Australian Geographer, 48(2), 185-202.

UK Gov. (2004). Hunting Act 2004. Retrieved from https:// www.legislation.gov.uk/ukpga/2004/37/contents

Williamson, H. (1927). Tarka the otter. London, UK: G. P. Putnam's Sons.

Williamson, H. (1933). The village book. London, UK: Jonathan Cape.

Williamson, H. (1944). Tales of the Devon village. London, UK: Faber and Faber.

Woods, M. (1998). Researching rural conflicts: Hunting, local politics and actor-networks. Journal of Rural Studies, 14, 321-340.

Woods, M. (2003). Deconstructing rural protest: The emergence of a new social movement. Journal of Rural Studies, 19, 309-25.

Woods, M. (2004). Politics and protest in the contemporary countryside. In L. Holloway \& M. Kneafsey (Eds.), Geographies of rural societies and cultures (pp. 103125). Aldershot, UK: Ashgate.

Wright Ltd. (2018). Modern poultry house facilityBroiler house. Retrieved from https://www.wright.ie/ case-study/modern-poultry-house-facility-broiler-houseco-monaghan/ 